別診断的価值を高めるものと思われる.

\section{4. スリットスキャノグラフイによる下肢動脈造影}

（第 2 報）

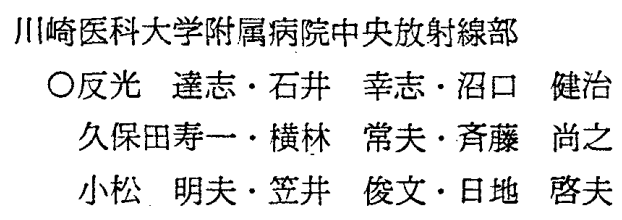

当院において，下肢全体の動脈造影を行なう場合，下 肢全体が間腺なく，大腿部から足部までの濃度の過不足 を補正し，かつ使用造影剤量を少量化し長尺方向の像の 歪み拉大を是正するために，濃度補賞型長尺カセッテを 使用した。管球移動方式のスリットスキャノグラフィを 施行している.

今回第 2 報として, 現在までに施行して得られた情報 から，当院における手法の問題点に考察を加え報告す る.

15. シンチスキャ+におけるスキャニング条件の一考 察

広島大学医学部附属病院 放射線部 ○山本 登·宮川 忠重·土井信一格

シンチグラムの画質に関係する因子は，被検者，装置 （娭出部・波高分析・出力装置）及び，記録条件・記 録 方法などがある、装置は Nuclear Chicago 社製 5 イン チ Rectilinear Scanner（Model 1775）を使用し，被検 体は実用の場合を考慮したPhantom について，最高計 数率部における計数率の標準誤差 $\left(\varepsilon_{n}\right)$ と, レコーダに 至った信号毎に露光された写真濃度 $\left(D_{1}\right)$ の統計的バラ ッキがシンチグラムの視覚的バラッキに関連するものと して，最高計数率值と走查速度の関係から，ホトシンチ グラムの画質を安定させる方法を試みたので報告する.

\section{質問}

ホトシンチグラフィで scanning speed が増すと, ス ライドの様に像が悪くなりますが，ホトシンチの Density を增し, フィルム上での単位面積当りの露光量を一 定にすると像はよくなるのではないでしょうか.

田中丸芳樹（広島）

\section{答}

スキャナにおいては出力特性より考えて調整しきれな い場合があり，露出を大きくしても画質の均一性はもつ かしい. これらの兼ねあいについては認知していない.

\section{6. 甲状腺スキャニングにおける若干の険討}

広島日赤病院 放射線科

○外溒 大一・吉竹 康人.江川 斉

〔目的〕ライン・ファントムを用いたシンチカメラ（ピ
ンホール・コリメータ) 像と, シンチスキャナ像の比較, 甲状腺被曝線量の検討などについて報告する。

[結果] シンチカメラによる ${ }^{99 \mathrm{~m}} \mathrm{Tc}$ ライン・ファントム の識別能が最すよく，シンチスキャナによる ${ }^{131}$ ラインン ・ファントムの識別能が最も悪かった. シンチスキャナ では核種による違いが明白だったが，シンチカメラでは， さはど明白ではなかった。 ${ }^{99 \mathrm{~m}} \mathrm{Tc} 2 \mathrm{mCi}$ 投与は ${ }^{131} \mathrm{I} 300$ $\mu \mathrm{Ci}$ 投与に比べて甲状腺被儤線量が約 $1 / 1000$ 亿減少する.

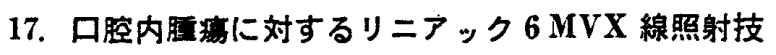
術の検討（第 1 報）

ミニコンピュータによる線量分布の計算

川旖医科大学附属病院中央放射線部

○沼口 健治・笠井 俊文・小松 明夫

斉藤 尚之・反光 達志・横林 常夫

久保田寿一・石井 幸志・日地 啓夫

口腔内腫湟の放射線治療では, 術者の被曝, 手技の煩 雑さ, 腫場の拉がりによる線量分布の不確かさ等と問題 が多い. 今回は患者の頭頙部及び舌の固定具を作製し， 対向 2 門照射, ウエッジヘア等の中より, 患者輪郭, 腫 演位置，腫瘍サイズ及び形状により適したものを選んで 照射し，治療計画用るニュンピュータPC-12により等線 量曲線を求めたもののうち, 主として $6 \mathrm{MVX}$ 線照射に よる治療技術についてその長所, 短所, 等線量曲線の精 度について述べたいと思う。

\section{8. 当院におけるリニアックの線量管理について}

国立岡山病院 小林 豊

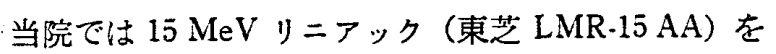
設置し，昭和 50 年3 月より治療を開始した.とれに伴な い, 臨床上，必要な線量管理について，現在行なってい る，X線，電子線のエネルギー測定，当院で武作した平 坦度スキャンニング装置を使っての平坦度測定法, 又ア イオネックス線量計を使ってのモニタ校正, 現在までの モニタ線量の管理状況等について垠告する.

\section{筫問}

1. 電子線のエネルギ一変化は経年的にはいかがなも のでしょうか.

2.モニタの変動は調整後のbのでしょうか. 砂屋敷 忠(広島)

\section{答}

1.はじめはメーカの指定通りと思っていたが，測 定をはじめてはじめて判った，測定を始めてからはマグ ネトロンを変えたばかりであと実施していないので不 明である.

2. 测定は整遇土曜日に行なうので，前週のものと比 
較したものである。

19. 放射線治痖における照射野トリミング材の比较検 討

広島大学病院 放射線部

○石見 義夫·玫島利男·谷口 金吾 土井信一格

広島大学 原医研 砂屋敷 忠

高エネルギ一放射線治療においては病巣の形に応じた 不整形照射野を多く要求される. 従来の鉛ブロックと在 意の照射野が比㦻的求め易い粒状鉛，及び低融点鉛との 遮蔽効果を比較検討した。

[方法]従来の鉛, 粒状鉛, 低融点鉛について, リニア ック $8 \mathrm{MVX}$ 線を用い減弱を測定した。又照射野内にお ける遮蔽材の辺縁での線量の変化を測定した.

〔結果〕 1) 鉛ブロックは遮蔽効果が最も良いが，工作 が困難で鉛の切口と入射角が平行でないととから均等な 線量分布が得難い，2）粒状鉛は遮蔽効果に均一性がな く，部位の設定が困難である，3）低融点鉛は遮蔽効果 あ充分であり，工作も容易でより効果的な治療結果が得 られる.

\section{追加}

鉛の品質について私の過去の体験において品質不良で はないかと考えられる鉛の使用による場合が 2 例ある.

(1). 遮へい能力が著しく低い.

(2). $5 \mathrm{~mm}$ の鉛がマッチで然える.

不良鉛があるとすれば規格を制定したらどうか。 小野昭人（広島）

\section{RI シンチの放射線治痖への応用}

倉敷中央病院放射線科 上田 良作

RI 検查は今日では診断部門の一分野として，急速の 進步をとげている。この RI 検查を放射線治療に利用し た経験について述へ，若干の考察を加えて発表する．そ の倹討事項は下記の通りである.

i ）治療目的腫瘍の形状・浸潤範囲.

ii）転移の有無.

iii）軟部組織腫瘍の恰出.

iv）治療効果の判定.

21. 各種放射性 Colloid の肝外集積に関する険討

川崎医科大学附属病院

○横林 常夫・日地 啓夫

肝 Scanning Agent として用いられている, ${ }^{99 m} \mathrm{Tc}$ Colloid 及びフチン酸は従来使用していた ${ }^{198} \mathrm{Au}$ とくら ベRESへの集積状態が異る.とれは ${ }^{99 \mathrm{~m}} \mathrm{Tc}$-Colloid の性 状によるものと思われる. したがって ${ }^{99 m} \mathrm{Tc}$-Colloidの肝
及び肝外 RES への集積の程度を, 特に骨髄 Scintigraphy に適切な Colloid を選択する目的で検討した。

22. ${ }^{198} \mathrm{Au}$-コロイドと ${ }^{99 \mathrm{~m}} \mathrm{TC}$-フチン酸による訮シン チグラフィの比較検討（特に仰卧位右側面像を中 心として)

国立高知病院放射線科

○垣内 詔二・㷊岡 芳哃・和田 貞治

肝疾患の診断法としてのシンチグラフィで，使用 RI は従来の ${ }^{198} \mathrm{Au}$-コロイドより毛 ${ }^{99 \mathrm{~m}} \mathrm{Tc}$ 標識化合物が多く 使われるようになった. ${ }^{99 \mathrm{~m}} \mathrm{Tc}$ 標識化合物での肝シンチ グラフィでは，多方向からスキャンすることが望まれて いるが，当院等の中小施設でシンチカメラの導入されて ない施設で，シンチスキャナを使用して 1 患者当り 4 方 向のスキャンは不可能に近い. 当院ではルーチンの肝シ ンチグラフィとして，正面及び仰臥位右側面の 2 方向か らシンチグラムを作成している，てれに関して特に右則 面を中心として ${ }^{198} \mathrm{Au}$-コロイドと ${ }^{99 \mathrm{~m}} \mathrm{Tc}$-フチン 酸での 比較検討を試みた，又シンチスキャナに関する基礎的検 討も加えて報告する.

\section{3. $99 \mathrm{~m} \mathrm{TC} \cdot \mathrm{DMSA}$ による姐スキャニング} 広島日赤病院放射線科 备 大一

腎スキャニング用放射性医薬品として, ${ }^{99 \mathrm{~m}} \mathrm{Tc} \cdot \mathrm{DMSA}$ が用いられるに至ったので, ファントムを用いた ${ }^{203} \mathrm{Hg}$ 之 ${ }^{99 \mathrm{~m}} \mathrm{Tc}$ の解像力比較や，㛑被曝線量の検討をした。 ${ }^{99 \mathrm{~m}} \mathrm{Tc}$ の解像力は ${ }^{203} \mathrm{Hg}$ に比べて，ほほ同じか若干良 い. ${ }^{99 \mathrm{~m}} \mathrm{Tc} \cdot \mathrm{DMSA} 2 \mathrm{mCi}$ 投与は ${ }^{203} \mathrm{Hg} \cdot$ chlormerodrin $300 \mu \mathrm{Ci}$ 投与に比へて，腎被曝線量が $1 / 17$ 亿减少する. ${ }^{99 m} \mathrm{Tc}$ の最適エネルギーとカウントの増加は，画質の良 い婜皮質像を得ることができる.また朋・脾が描出され る例もあった. ${ }^{99 m} \mathrm{Tc} \cdot \mathrm{DMSA}$ は標識が簡単で，腎被曝 が少なく, ${ }^{203} \mathrm{Hg} \cdot$ chlormerodrin 倅って使用される変 のと考える.

\section{翼問}

1.コリメータの焦点は.

2. 実験では焦点距離 $7 \mathrm{~cm}$ でしていますが、それを 変えた場合，例えば $10 \mathrm{~cm}$ 亿すればズレがあるか.

佐藤大命 (愛媛)

\section{答}

1. ${ }^{99 \mathrm{~m} T \mathrm{c}}$ 用は $10 \mathrm{~cm}$ で, $15 \mathrm{~cm}$ 用としてデータを出 した.

2.データとしては $15 \mathrm{~cm}$ 用ではないが, $10 \mathrm{~cm}$ では 内側になったと思うか，現在手もとに資料がない。

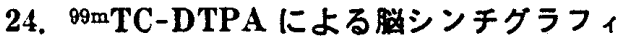
會敖中央病院 放射線科 